\title{
CHRYMUTASINS: NOVEL-AGLYCONE ANTITUMOR ANTIBIOTICS FROM A MUTANT OF Streptomyces chartreusis

\author{
II. CHARACTERIZATION AND STRUCTURAL ELUCIDATION
}

\author{
Hideaki Uchida ${ }^{\dagger}$, Yasukazu Nakakita, Nobuyasu Enoki, \\ Naoki Abe, Takehiko Nakamura and Masanobu Munekata \\ Pharmaceutical Research Laboratories, Sapporo Breweries Ltd., \\ 10 Okatohme, Yaizu, Shizuoka 425 Japan
}

(Received for publication November 8, 1993)

\begin{abstract}
Chrymutasins A, B and C are glycosidic antibiotics produced by a mutant of the chartreusin producer-organism Streptomyces chartreusis. We report here the structure elucidation of these compounds. The sugar moieties involved were determined by comparison with the related chartreusins. The structure of the aglycone, the same in all three compounds, was elucidated by NMR, incorporation studies of labeled compounds and synthesis of derivatives. The chrymutasin aglycone differs from that of chartreusin by a single carbon and an amino group.
\end{abstract}

The chrymutasins ${ }^{1)}$ are novel antitumor antibiotics produced by Streptomyces chartreusis D329-185. Chrymutasins A (1), B (2) and C (3) are related compounds corresponding to chartreusin ${ }^{2)}$ (4), demethylchartreusin ${ }^{3)}(5)$ and the compound $\mathrm{D} 329 \mathrm{C}^{4)}(6)$, respectively (Fig. 1). In the preceding paper ${ }^{5)}$ the

Fig. 1. Structures of chrymutasins, chartreusin and related compounds.

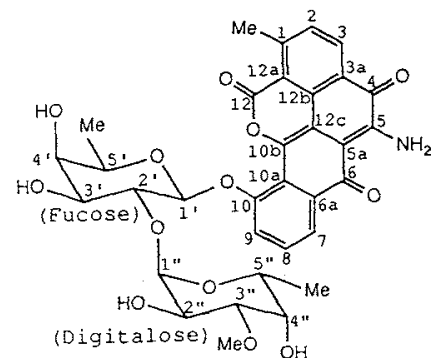

Chrymutasin A (1)

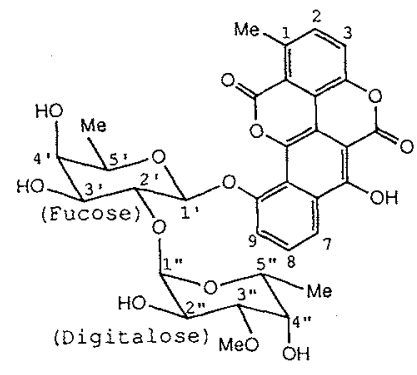

Chartreusin (4)
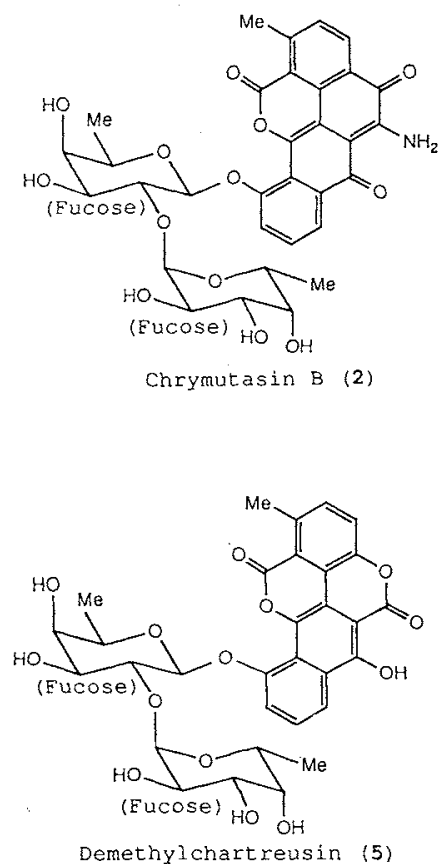

(5)
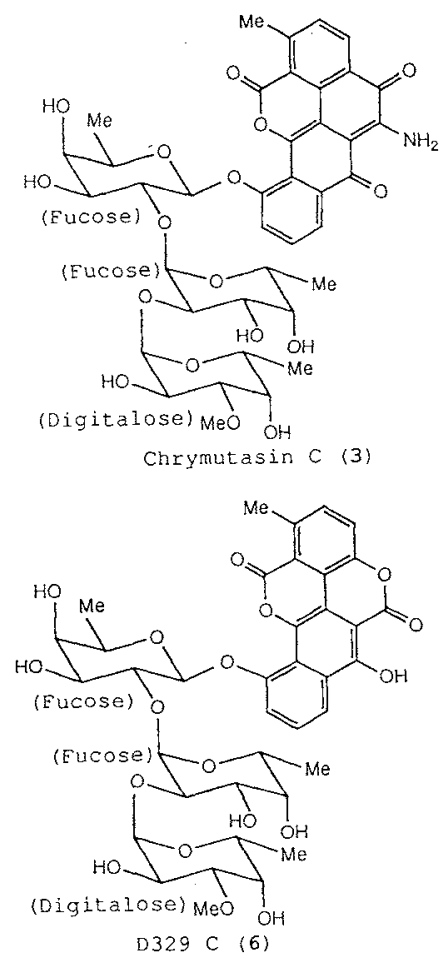

Present address: Faculty of Pharmacy, Meijo University, Tempaku-ku, Nagoya 468, Japan 
taxonomy, mutation, fermentation, isolation and biological activities of chrymutasins have been described. In this paper, we report the structure elucidation of the chrymutasins.

\section{Results and Discussion}

Compound 1, $\mathrm{C}_{33} \mathrm{H}_{33} \mathrm{NO}_{13}$, isolated as a violet powder, showed a characteristic UV absorption (Fig. 2). ${ }^{1} \mathrm{H}$ and ${ }^{13} \mathrm{C}$ NMR data are shown in Table 1 . Other physico-chemical properties are shown in Table

2. The structure elucidation of the sugars and aglycone of $\mathbf{1}$ are described separately below. Comparison

Fig. 2. UV spectra of chrymutasin A (1), chartreusin (4) and compound 9.
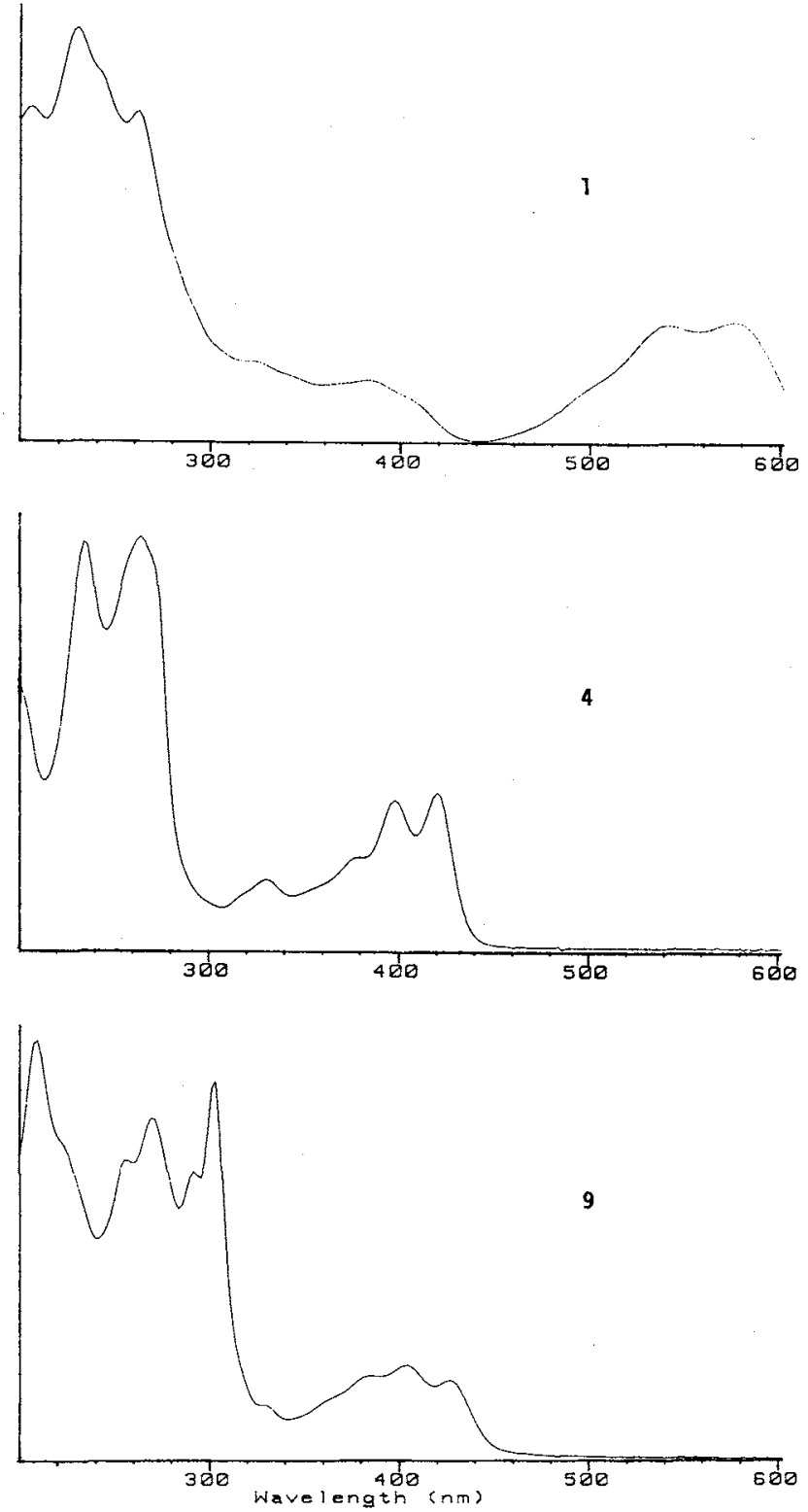

These UV spectra were measured on a HPLC system having a photodiode array with gradient $\left(\mathrm{CH}_{3} \mathrm{CN}-\mathrm{H}_{2} \mathrm{O}\right.$, at neutral $\left.\mathrm{pH}\right)$. 
was made with the data for $4(4,5$ and 6 were also isolated from fermentations of the same strain.).

\section{Sugars}

It was assumed that the sugars of $\mathbf{1}$ and $\mathbf{4}$ were the same by a direct comparison of the NMR data

Table 1. ${ }^{1} \mathrm{H}$ and ${ }^{13} \mathrm{C}$ NMR data for chrymutasins $\mathrm{A}, \mathrm{B}$ and $\mathrm{C}$.

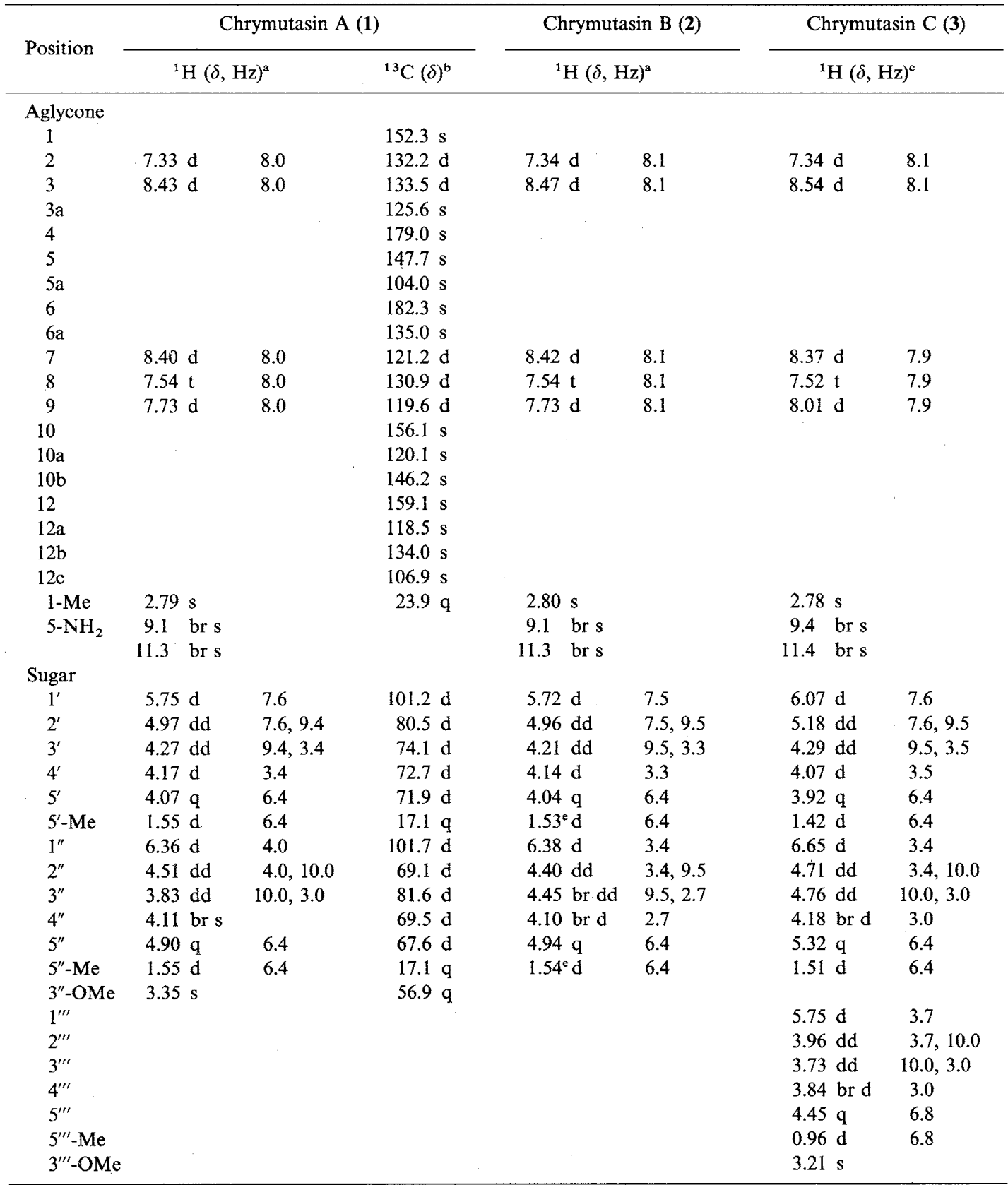

a ${ }^{1} \mathrm{H}$ NMR: $400 \mathrm{MHz}$, pyridine- $d_{5}, 50^{\circ} \mathrm{C}$.

b ${ }^{13} \mathrm{C}$ NMR: $100 \mathrm{MHz}$, pyridine- $d_{5}, 50^{\circ} \mathrm{C}$.

c ${ }^{1} \mathrm{H}$ NMR: $400 \mathrm{MHz}$, pyridine- $d_{5}$, room temperature.

e Assignments may be reversed. 
Table 2. Physico-chemical properties of chrymutasins A, B and C.

\begin{tabular}{|c|c|c|c|}
\hline & Chrymutasin $\mathrm{A}$ & Chrymutasin B & Chrymutasin $\mathrm{C}$ \\
\hline Appearance & Violet powder & Violet powder & Violet powder \\
\hline Molecular formular & $\mathrm{C}_{33} \mathrm{H}_{33} \mathrm{NO}_{13}$ & $\mathrm{C}_{32} \mathrm{H}_{31} \mathrm{NO}_{13}$ & $\mathrm{C}_{39} \mathrm{H}_{43} \mathrm{NO}_{17}$ \\
\hline \multicolumn{4}{|l|}{ HRFAB-MS $(m / z)$} \\
\hline Mode & Positive & Negative & Positive \\
\hline Found: & $676.2039\left(\mathrm{M}+\mathrm{Na}+\mathrm{H}_{2}\right)^{+}$ & $637.1791(\mathrm{M})^{-}$ & $820.2423(\mathrm{M}+\mathrm{Na})^{+}$ \\
\hline Calcd: & 676.2006 & 637.1796 & 820.2428 \\
\hline$[\alpha]_{\mathrm{D}}^{20}(c 0.001$, pyridine $)$ & $-100,000$ & $-220,000$ & $-24,000$ \\
\hline \multicolumn{4}{|c|}{$\mathrm{UV} \lambda_{\max } \operatorname{nm}(\varepsilon)$} \\
\hline in $\mathrm{MeOH}$ & $\begin{array}{l}228(16,000) \\
\quad 243(13,000, \mathrm{sh}) \\
262(12,000), 385(2,600), \\
534(5,200), 572(5,600)\end{array}$ & $\begin{array}{l}229(20,000), \\
242(18,000, \mathrm{sh}) \\
262(17,000), 385(5,600), \\
534(7,200), 570(7,600)\end{array}$ & $\begin{array}{l}231(26,000), \\
243(23,000, \mathrm{sh}), \\
263(22,000), 387(4,800), \\
537(9,600), 573(10,000)\end{array}$ \\
\hline $\begin{array}{l}\text { in } 0.1 \mathrm{~N} \\
\quad \mathrm{NaOH}-\mathrm{MeOH}\end{array}$ & $\begin{array}{l}215(44,000), 249(12,000) \\
270(8,800), 365(3,600) \\
\quad 675(2,000)\end{array}$ & $\begin{array}{l}216(43,000), 242(22,000), \\
\quad 270(16,000), 365(6,400), \\
\quad 680(4,000)\end{array}$ & $\begin{array}{l}216(44,000), 243(23,000) \\
\quad 265(18,000), 365(6,400) \\
\quad 670(3,200)\end{array}$ \\
\hline IR $v_{\max }(\mathrm{KBr}) \mathrm{cm}^{-1}$ & $\begin{array}{l}3430,2940,1730,1590 \\
1300,1080,1060\end{array}$ & $\begin{array}{l}3450,2930,1720,1590 \\
1280,1070\end{array}$ & $\begin{array}{l}3430,2920,1730,1590 \\
\quad 1290,1070\end{array}$ \\
\hline MP $\left({ }^{\circ} \mathrm{C}\right)$ & $183 \sim 198$ & $249 \sim 255$ & $188 \sim 192$ \\
\hline \multicolumn{4}{|l|}{ TLC Rf value ${ }^{\mathrm{a}}$} \\
\hline $\begin{array}{c}\mathrm{CH}_{2} \mathrm{Cl}_{2}-\mathrm{MeOH} \\
(85: 15)\end{array}$ & 0.68 & 0.42 & 0.24 \\
\hline $\begin{array}{l}\mathrm{CH}_{2} \mathrm{Cl}_{2}-\mathrm{MeOH} \\
(90: 10)\end{array}$ & 0.41 & 0.12 & 0.09 \\
\hline $\begin{array}{l}\text { EtOAc- } \mathrm{MeOH} \\
(80: 20)\end{array}$ & 0.46 & 0.22 & 0.16 \\
\hline
\end{tabular}

a Silica gel TLC (Merck Art. No. 5554).

of the sugar moieties of 1 with those of 4 (Figs. 3 and 4). In order to confirm this assumption, the trimethylsilyl derivatives of the sugars obtained from the hydrolysis of 1 and 4 were analyzed with GC-MS using similar methods ${ }^{4)}$. These analyses show that the derivatives of $\mathbf{1}$ and $\mathbf{4}$ gave the same chromatograms and MS fragment patterns (Fig. 5). These results confirm that the sugars of 1 consisted of one molar equivalent of fucose and one equivalent of digitalose.

The connective order of the sugars was determined from the NOESY experiments (Fig. 6). In addition, this was supported by the NOEs of the tetraacetate derivative (7).

The constituent sugars of 2 and 3 (Fig. 1) were determined by GC-MS analysis of the trimethylsilyl derivatives of the sugars in a manner similar to that previously described (Fig. 5) and by detailed comparison of their NMR data (Tables 1 and 3; Figs. 3, 4, 7, 8 and 9). The ${ }^{1} \mathrm{H}$ NMR spectrum of the sugars of 2 (Fig. 7) was similar to that of 1 (Fig. 3) except for the $3^{\prime \prime}$-proton of the fucose, because of the presence of a hydroxyl group rather than a methoxyl group of 1 . In the case of 3 (Fig. 8) and 6 (Fig. 9), the sugar resonances of the two spectra were similar except for $2^{\prime \prime \prime}$-proton and $3^{\prime \prime \prime}$-methoxyl group of the digitalose. This difference is attributable to the anisotropy effect for their different conformation. Analyzing NOEs of $6\left(9-\mathrm{H} \leftrightarrow 1^{\prime}-\mathrm{H}, 2^{\prime}-\mathrm{H} \leftrightarrow 1^{\prime \prime}-\mathrm{H}, 1^{\prime \prime}-\mathrm{H} \leftrightarrow 1^{\prime \prime \prime}-\mathrm{H}\right), 3^{\prime \prime \prime}$-OMe $(\delta 3.58)$ seemed to be roughly located on the aglycone plane and $2^{\prime \prime \prime}$-proton $(\delta 3.53)$ roughly placed over the plane ${ }^{4)}$. On the other hand, two pairs of NOEs (9-H↔1'-H and $1^{\prime \prime}-\mathrm{H} \leftrightarrow 1^{\prime \prime \prime}-\mathrm{H}$ ) were observed in 3 but no NOE was between $2^{\prime}-\mathrm{H}$ and $1^{\prime \prime}-\mathrm{H}$. It was presumed that the digitalose in $\mathbf{3}$ was not near the aglycone. Therefore, $3^{\prime \prime \prime}$-methoxyl group in $\mathbf{3}$ showed a higher chemical shift ( $\delta 3.21)$ than that of 6 and $2^{\prime \prime \prime}$-proton in $\mathbf{3}$ showed a lower one $(\delta 3.96)$ than that of $\mathbf{6}$. 
Fig. 3. ${ }^{1} \mathrm{H}$ NMR spectrum of chrymutasin A (1). $\left(400 \mathrm{MHz}\right.$, pyridine- $\left.d_{5}, 50^{\circ} \mathrm{C}\right)$.

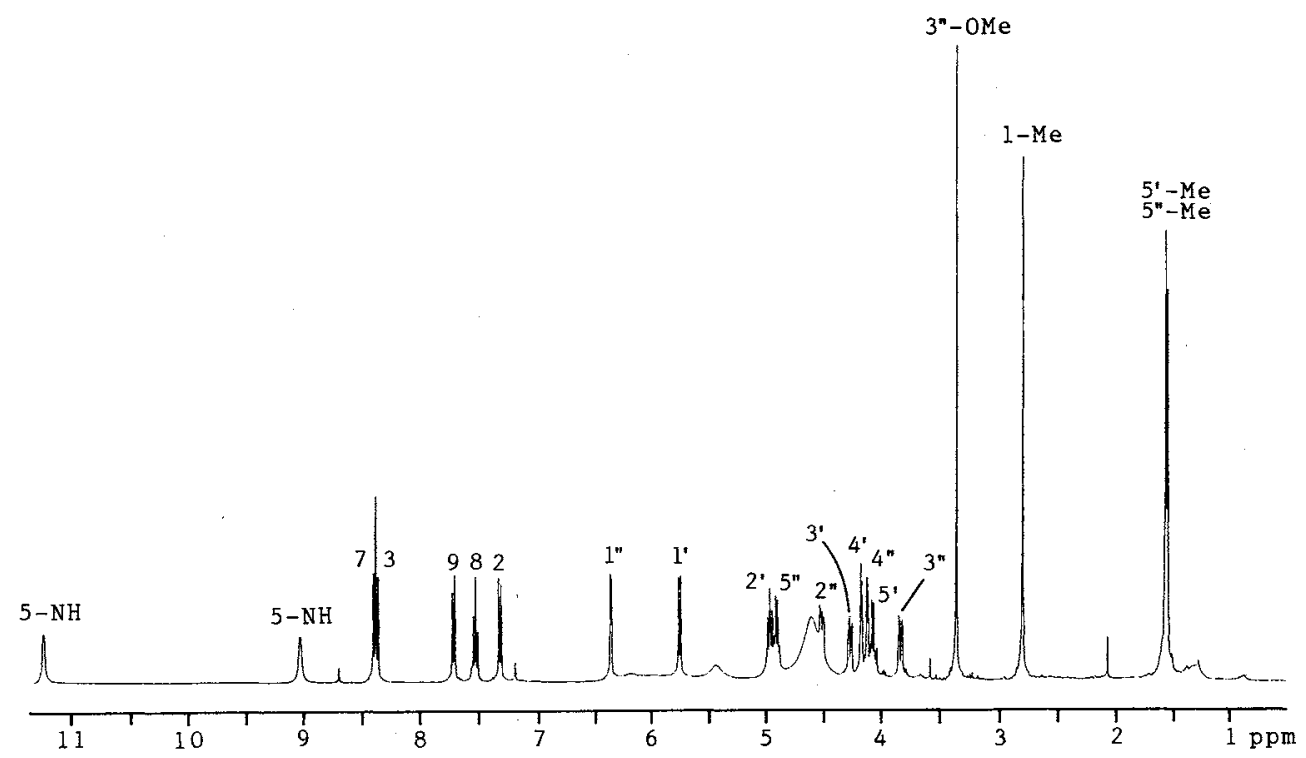

Fig. 4. ${ }^{1} \mathrm{H}$ NMR spectrum of chartreusin (4). (400 MHz, pyridine- $d_{5}, 50^{\circ} \mathrm{C}$ ).

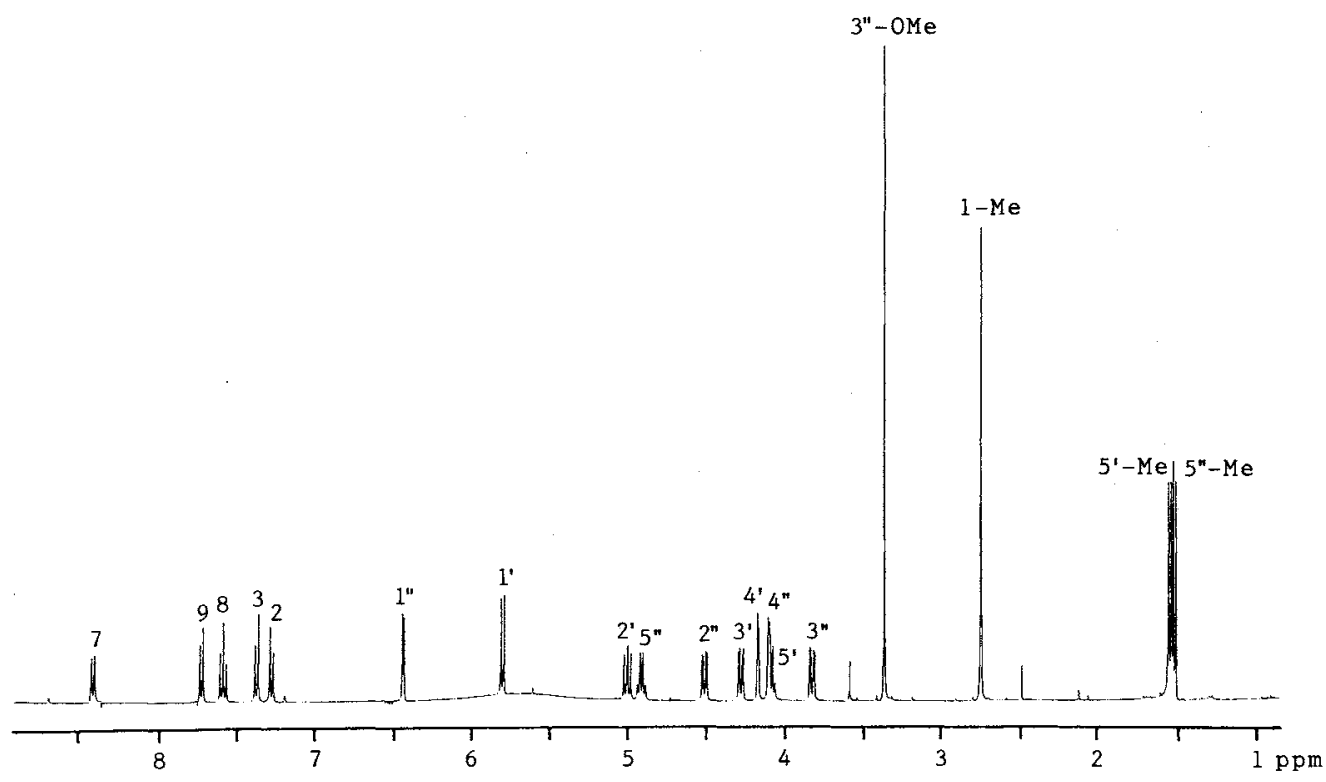

Aglycone

The similar UV spectra (Table 2) of 1, 2 and 3 immediately suggested that these compounds had the same chromophore. The aglycones from 1, 2 and 3 had the same retention time on HPLC, thereby confirming that these three compounds had the same aglycone, chrymutin (8).

Some experiments, which determined the aglycone structure and the assignments of the ${ }^{13} \mathrm{C} \mathrm{NMR}$, are described below. Since $\mathbf{8}$ was poorly soluble in most NMR solvents, the NMR analysis of the aglycone 
Fig. 5. GC-MS of sugar derivatives.
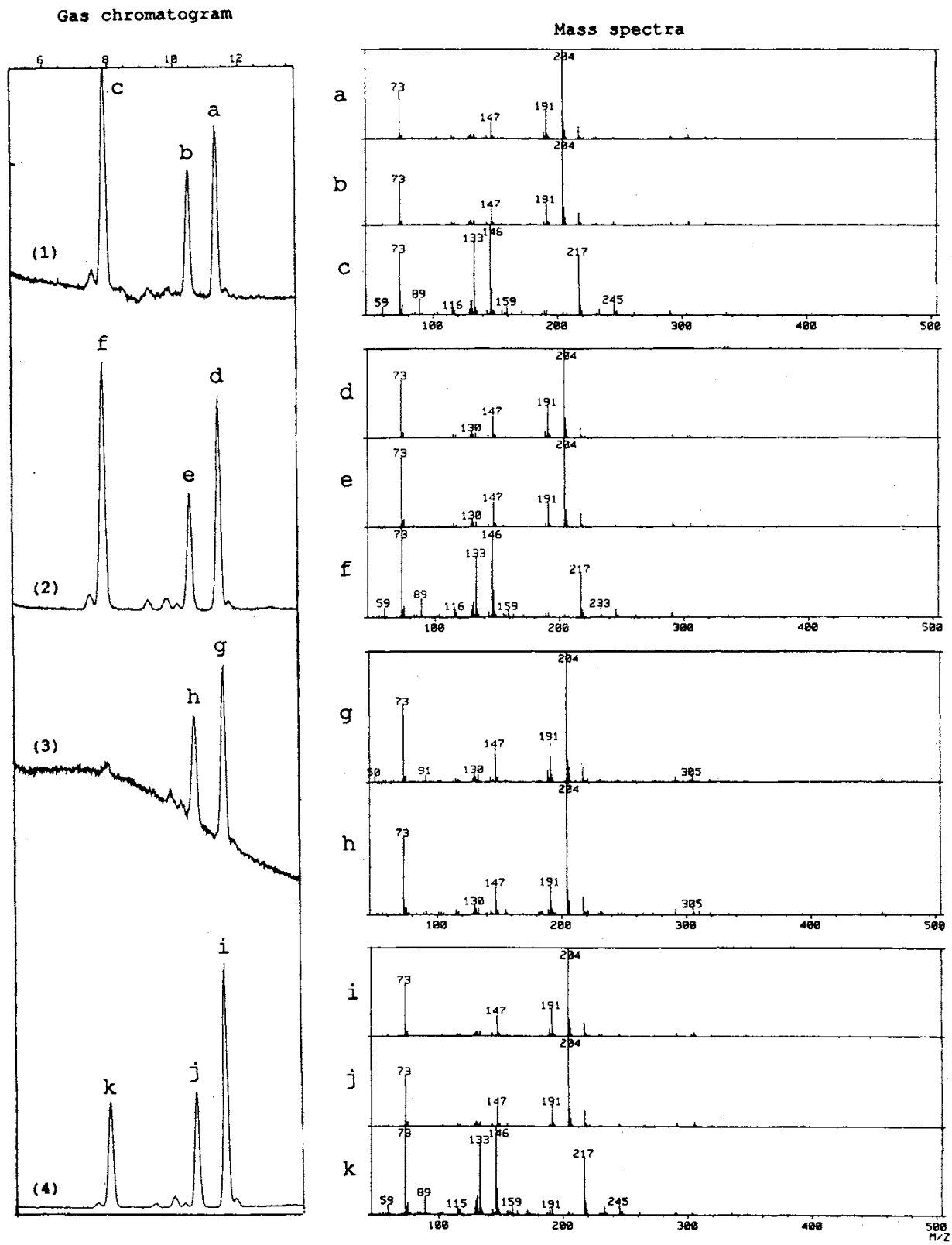

(1) Trimethylsilyl-derivatives of fucose and digitalose from chartreusin. (2) Trimethylsilyl-derivatives of the sugars from chrymutasin A (1). (3) Trimethylsilyl-derivatives of the sugars from chrymutasin B (2). (4) Trimethylsilyl-derivatives of the sugars from chrymutasin $\mathrm{C}$ (3).

moiety was carried out with 1 . The complete decoupling, DEPT, and ${ }^{13} \mathrm{C}-{ }^{1} \mathrm{H}$ HETCOR data revealed the direct connection of five aromatic protons to five carbons and all of the assignments of the sugar carbons (Fig. 10). The ${ }^{13} \mathrm{C}-{ }^{1} \mathrm{H}$ long range $\operatorname{COSY}(8 \mathrm{~Hz})$ permitted the assignments of fourteen of the twenty aglycone carbons (Fig. 11). 
Two broad peaks ( $\delta 9.3$ and 11.3 ) in the ${ }^{1} \mathrm{H}$ NMR spectra were coupled to each other (by COSY) and disappeared with addition of $\mathrm{D}_{2} \mathrm{O}$. HR-MS revealed the presence of one nitrogen atom, and 1 was basic property, therefore, the presence of a $\mathrm{NH}_{2}$ group was assumed.

In addition to the data described above, the carbon skeleton of the aglycone was anticipated to be closely related to chartarin ${ }^{6)}$, thus a proposed aglycone structure was arrived at (Fig. 10). It was shown that two carbons ( $\delta 179.0$ and 104.0) were coupled to two amino protons using LSPD (long-range selective proton decoupling) experiments (Figs. 10 and 12). Two carbons ( $\delta 147.7$ and 106.9) were uncoupled to any protons, and consequently, the LSPD experiment could not be applied.

In order to determine the assignments of the remaining four carbons $(\delta 159.1,147.7,146.2$ and 106.9), the incorporation of ${ }^{13} \mathrm{C}$ labeled precursors was tried. A previous report ${ }^{7)}$ has demonstrated that chartarin was biosynthesized via a polyketide pathway. First incorporation of ${ }^{13} \mathrm{C}$ in $\mathbf{4}$ by cultivation of the mutant strain with sodium $\left[1-{ }^{13} \mathrm{C}\right]$ acetate was verified. Subsequently, singly and doubly ${ }^{13} \mathrm{C}$ labeled 1 were isolated from fermentations as previously described ${ }^{5)}$ for unlabeled 1 . Results of the ${ }^{13} \mathrm{C}$ NMR experiments are shown in Table 4. Nine pairs of ${ }^{13} \mathrm{C}-{ }^{13} \mathrm{C}$ direct connections from labeled acetate are summarized in Fig. $13 .{ }^{13} \mathrm{C}-{ }^{13} \mathrm{C}$ direct couplings indicated the assignments of $\mathrm{C}_{4}(\delta 179.0), \mathrm{C}_{12}(\delta$ $159.1) \mathrm{C}_{12 \mathrm{c}}(\delta 106.9)$ and $\mathrm{C}_{5 \mathrm{a}}(\delta 104.0)$.

For the remaining two carbons $(\delta 147.7,146.2)$, ${ }^{2} J_{\mathrm{C}-\mathrm{D}}\left({ }^{13} C-\mathrm{N}-D\right)$ coupling and an isotope shift (about $0.5 \mathrm{ppm}$ ) to high field of the carbon at $\delta 147.7$ appeared with the addition of $\mathrm{D}_{2} \mathrm{O}$ (Fig. 14). Therefore, the carbon at $\delta 147.7$ was directly connected to the $\mathrm{NH}_{2}$ group, and assignment of the

Fig. 6. NOEs of chrymutasin A (1)

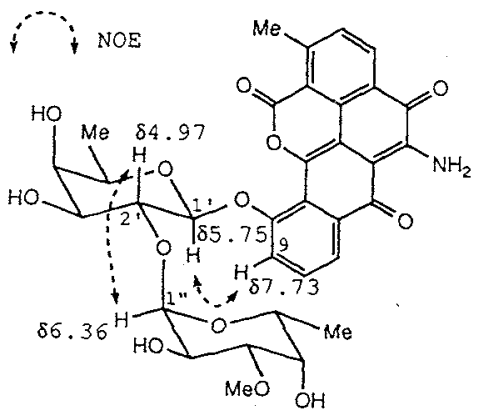

Table 3. ${ }^{13} \mathrm{C}$ NMR data for chrymutasins A, B and C. (100 MHz, pyridine- $d_{5}$, room temperature).

\begin{tabular}{ccc|ccc}
\hline $\begin{array}{c}\text { Chrymutasin A } \\
{ }^{13} \mathrm{C}(\delta)\end{array}$ & $\begin{array}{c}\text { Chrymutasin B } \\
{ }^{13} \mathrm{C}(\delta)\end{array}$ & $\begin{array}{c}\text { Chrymutasin C } \\
{ }^{13} \mathrm{C}(\delta)\end{array}$ & $\begin{array}{c}\text { Chrymutasin A } \\
{ }^{13} \mathrm{C}(\delta)\end{array}$ & $\begin{array}{c}\text { Chrymutasin B } \\
{ }^{3} \mathrm{C}(\delta)\end{array}$ & $\begin{array}{c}\text { Chrymutasin C } \\
{ }^{13} \mathrm{C}(\delta)\end{array}$ \\
\hline 182.0 & 182.2 & 182.3 & 100.9 & 101.0 & 96.6 \\
178.8 & 179.0 & 179.3 & 81.6 & 80.5 & 96.3 \\
158.9 & 159.0 & 158.9 & 80.2 & 74.1 & 81.3 \\
156.1 & 156.2 & 155.2 & 74.2 & 73.5 & 77.9 \\
152.2 & 152.2 & 152.1 & 72.7 & 72.6 & 73.63 \\
147.8 & 147.9 & 147.9 & 71.9 & 71.9 & 73.56 \\
145.9 & 146.0 & 145.9 & 69.4 & 71.9 & 73.4 \\
134.9 & 134.9 & 135.0 & 69.0 & 70.5 & 72.9 \\
133.7 & 133.9 & 134.3 & 67.4 & 67.6 & 71.6 \\
133.4 & 133.4 & 133.4 & 56.8 & 24.0 & 69.9 \\
132.2 & 132.1 & 132.0 & 24.1 & 17.2 & 68.7 \\
130.8 & 130.9 & 130.7 & 17.2 & 17.1 & 68.6 \\
125.3 & 125.4 & 125.7 & 17.1 & & 67.1 \\
120.9 & 121.0 & 121.4 & & & 66.9 \\
119.8 & 119.8 & 120.7 & & & 56.5 \\
119.1 & 119.2 & 120.2 & & & 17.2 \\
118.3 & 118.4 & 118.8 & & & 17.0 \\
106.8 & 106.8 & 107.2 & & & \\
103.7 & 103.8 & 104.1 & & & \\
101.8 & 102.1 & 100.5 & & & \\
\hline
\end{tabular}


Fig. 7. ${ }^{1} \mathrm{H}$ NMR spectrum of chrymutasin $\mathrm{B}(2) .\left(400 \mathrm{MHz}\right.$, pyridine- $\left.d_{5}, 50^{\circ} \mathrm{C}\right)$.

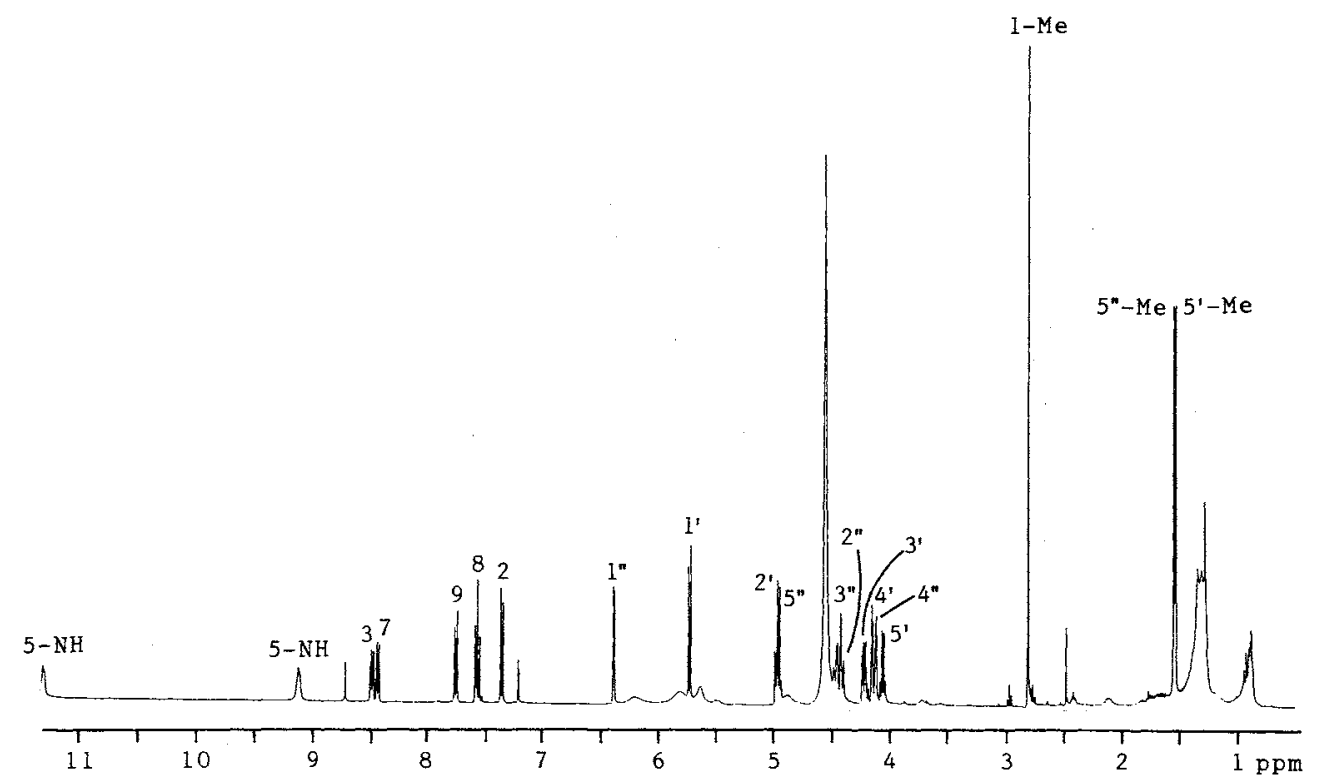

Fig. 8. ${ }^{1} \mathrm{H}$ NMR spectrum of chrymutasin $\mathrm{C}(3)$. (400 MHz, pyridine- $d_{5}$, room temperature).

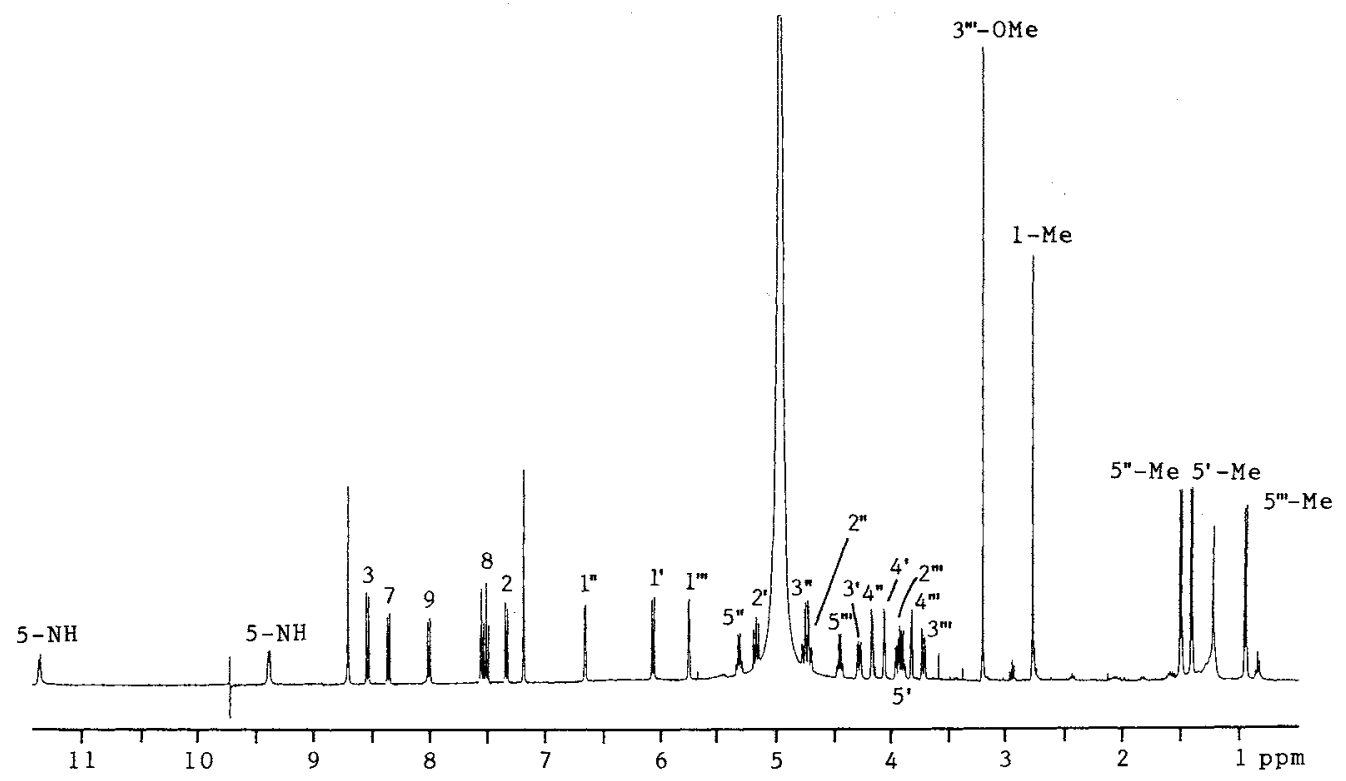

remaining carbon $(\delta 146.2)$ to the $\mathrm{C}_{10 \mathrm{~b}}$ position was made.

The presence of a quinone had been presumed from the UV and ${ }^{13} \mathrm{C}$ NMR spectra of 1 , therefore, an attempt to synthesize the acetate of the reduction products of $\mathbf{1}$ and $\mathbf{8}$ was made (Scheme 1). Compound 7 , having been acetylated on only the four sugar hydroxyl groups, was obtained from $\mathbf{1}$ under mild acetylation conditions. On the other hand, yellow compound 9 , which was the reductive acetylation product of $\mathbf{1}$, was obtained upon addition of a catalytic amount of zinc powder. Compound $\mathbf{9}$ was also synthesized 
Fig. 9. ${ }^{1} \mathrm{H}$ NMR spectrum of D329C (6). (400 MHz, pyridine- $\left.d_{5}, 60^{\circ} \mathrm{C}\right)$.

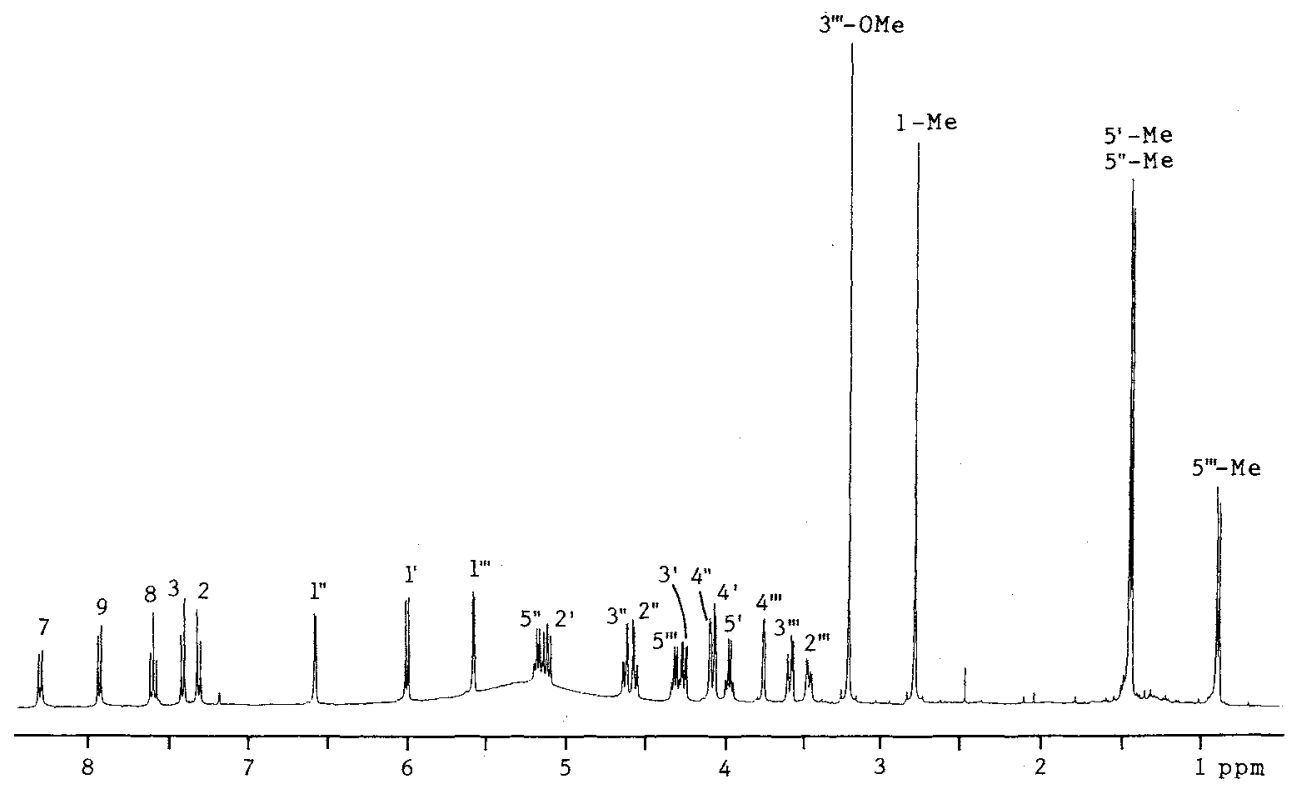

Fig. 10. Summary of observed ${ }^{13} \mathrm{C}^{-1} \mathrm{H}$ coupling $\left({ }^{13} \mathrm{C}-{ }^{1} \mathrm{H}\right.$ COSY and LSPD) for the aglycone of chrymutasin A (1).

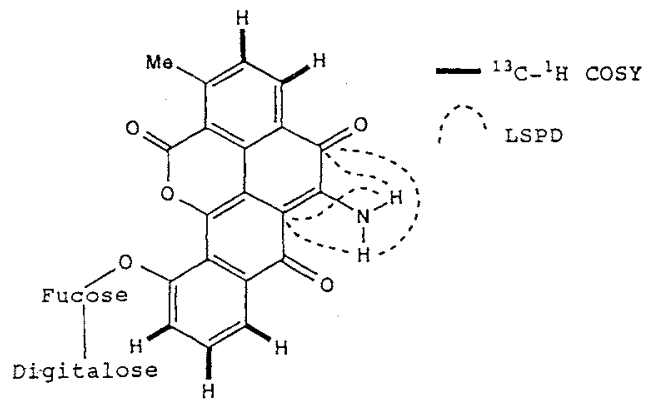

Fig. 11. Summary of observed ${ }^{13} \mathrm{C}-{ }^{1} \mathrm{H}$ coupling $\left({ }^{13} \mathrm{C}-{ }^{1} \mathrm{H}\right.$ long-range COSY, $\left.8 \mathrm{~Hz}\right)$ for the aglycone of chrymutasin A (1).

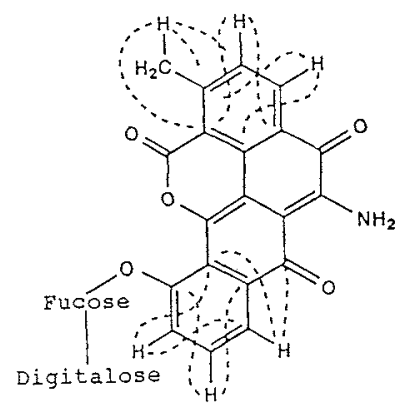

under heated acetylation conditions $\left(80^{\circ} \mathrm{C}\right)$ from 1 or reductive acetylation conditions from 7 . The alkaline hydrolysis product of 9 showed the same retention time as that of 1 on HPLC analysis. Although good spectral data for $\mathbf{8}$ could not be obtained, the structure of $\mathbf{1 0}$ (the reductive acetate of $\mathbf{8}$ ) was confirmed by ${ }^{1} \mathrm{H}$ NMR and MS spectra.

Therefore, the structure of $\mathbf{8}$ was confirmed as previously described. The complete structures of 1,2 and 3 are shown in Fig. 1.

\section{Experimental}

General Procedures

High and low resolution MS were recorded on a JEOL JMS-SX102 mass spectrometer. ${ }^{1} \mathrm{H}$ and ${ }^{13} \mathrm{C}$ NMR data were taken on a Varian VXR-400 and a Bruker AM-500 spectrometers. Optical rotations were measured on a HORIBA SEPA-200 polarimeter. IR spectra were recorded on a Hitachi 270-30 infrared spectrophotometer. Melting points were measured on a Yanako micromelting point ap- 
Fig. 12. LSPD experiment of chrymutasin A (1).

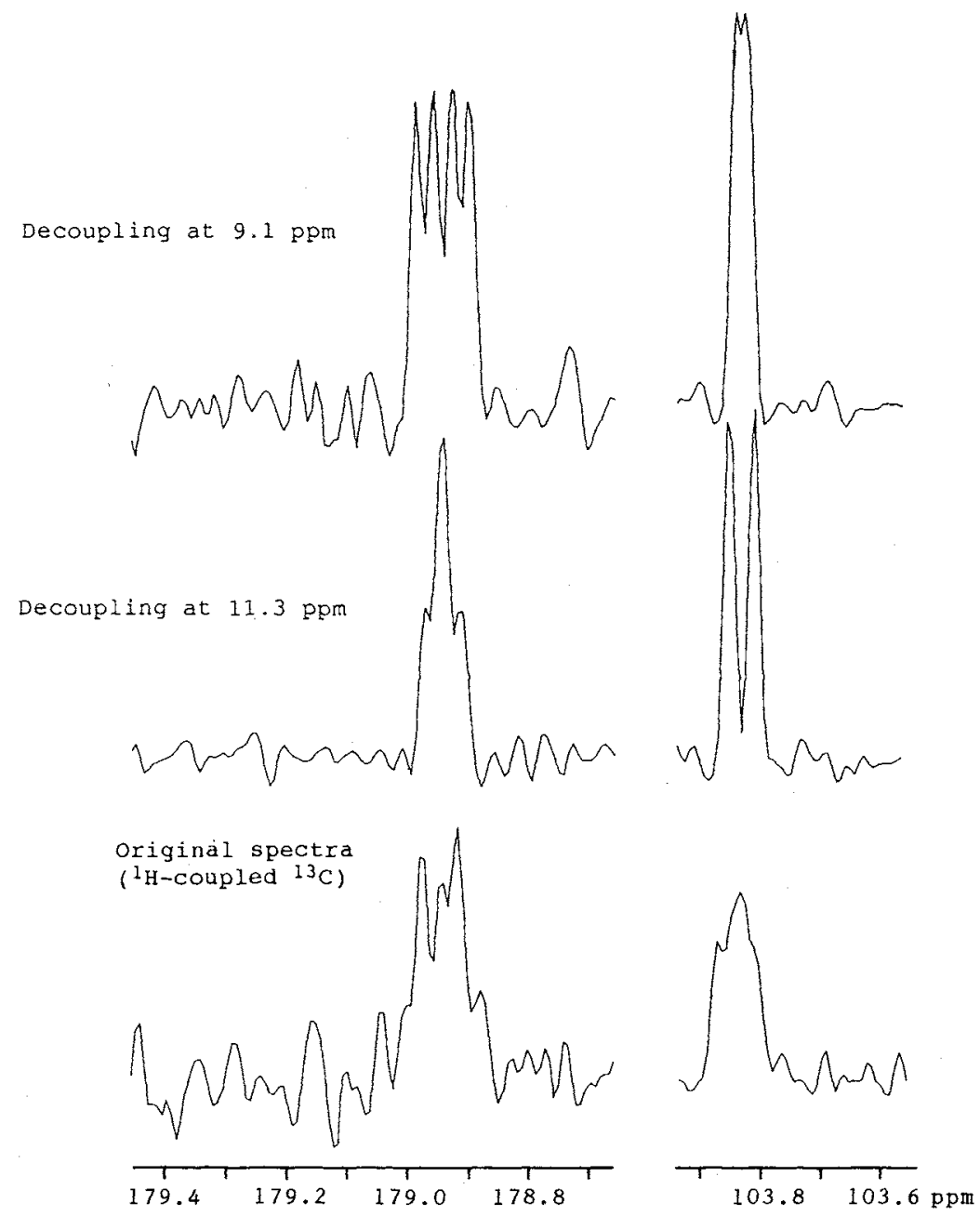

Table 4. Isotopic enrichment in chrymutasin A from cultures containing singly and doubly ${ }^{13} \mathrm{C}$ labeled acetates.

\begin{tabular}{|c|c|c|c|c|c|c|c|}
\hline \multirow[b]{2}{*}{$\begin{array}{l}\text { Aglycone } \\
\text { carbon }\end{array}$} & \multicolumn{3}{|c|}{ Position of label in precursor } & \multirow[b]{2}{*}{$\begin{array}{l}\text { Aglycone } \\
\text { carbon }\end{array}$} & \multicolumn{3}{|c|}{ Position of label in precursor } \\
\hline & $\begin{array}{l}{\left[1,2{ }^{13} \mathrm{C}_{2}\right]} \\
{ }^{1} J_{\mathrm{C}-\mathrm{C}}(\mathrm{Hz})\end{array}$ & $\begin{array}{c}{\left[1{ }^{13} \mathrm{C}\right]} \\
\text { Relative } \\
\text { intensity }^{\mathrm{b}}\end{array}$ & $\begin{array}{c}{\left[2{ }^{13} \mathrm{C}\right]} \\
\text { Relative } \\
\text { intensity }^{\mathrm{b}}\end{array}$ & & $\begin{array}{l}{\left[1,2-{ }^{13} \mathrm{C}_{2}\right]} \\
{ }^{1} J_{\mathrm{C}-\mathrm{C}}(\mathrm{Hz})\end{array}$ & $\begin{array}{l}{\left[1-{ }^{13} \mathrm{C}\right]} \\
\text { Relative } \\
\text { intensity }^{\mathrm{b}}\end{array}$ & $\begin{array}{l}{\left[2{ }^{13} \mathrm{C}\right]} \\
\text { Relative } \\
\text { intensity }^{\mathrm{b}}\end{array}$ \\
\hline $\mathrm{Me}$ & 42.1 & 1.1 & 3.7 & $\mathrm{C}-6 \mathrm{a}$ & 60.8 & 2.3 & 1.2 \\
\hline C-1 & 41.9 & 3.6 & 1.4 & C-9 & 56.2 & 1.1 & 2.9 \\
\hline $\mathrm{C}-2$ & 56.2 & 1.1 & 3.0 & C-8 & 56.2 & 4.0 & 1.2 \\
\hline $\mathrm{C}-3$ & 56.1 & 4.4 & 1.4 & C-10a & 71.1 & 0.8 & 2.2 \\
\hline C-3a & 60.2 & 0.7 & 2.0 & $\mathrm{C}-10$ & 70.7 & 2.6 & 1.0 \\
\hline $\mathrm{C}-4$ & 60.0 & 2.0 & 1.0 & $\mathrm{C}-10 \mathrm{~b}$ & - & 2.4 & 1.1 \\
\hline C-5 & - & 1.0 & 2.1 & $\mathrm{C}-12 \mathrm{a}$ & 73.4 & 1.0 & 3.0 \\
\hline $\mathrm{C}-6$ & 58.5 & 0.8 & 3.0 & C-12 & 73.4 & 2.2 & 1.0 \\
\hline C-5a & 58.2 & 2.5 & 1.2 & $C-12 c$ & 53.4 & 1.0 & 2.7 \\
\hline $\mathrm{C}-7$ & 60.5 & 0.8 & 2.8 & $C-12 b$ & 53.4 & 2.5 & 0.9 \\
\hline
\end{tabular}

a ${ }^{13} \mathrm{C}$ NMR $(100 \mathrm{MHz})$ was measured in pyridine- $d_{5}$ at $60^{\circ} \mathrm{C}$.

b Each relative intensity was calculated taking an average signal height of sugar carbons as 1.0 . 
Fig. 13. Labeling pattern of 1.

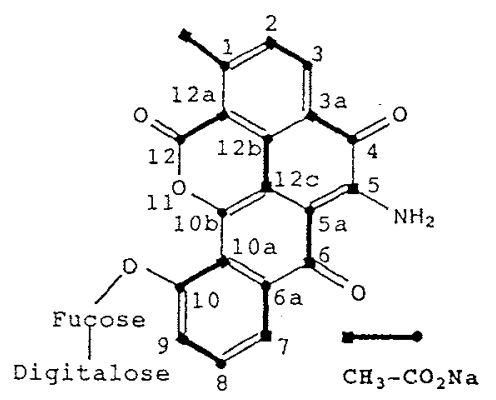

paratus MP-500D and are uncorrected. UV spectra were recorded using a Hitachi 200-20 spectrophotometer and a Hewlett Packard HP1090 Liquid chromatograph diode array spectrometer. Gas chromatograms were recorded on a Shimadzu GC-9A.

Analyses of the Sugars and the Aglycones of the Chrymutasins

Compound $1(1.3 \mathrm{mg}, 0.002 \mathrm{mmol})$ was stirred at $100^{\circ} \mathrm{C}$ in $0.2 \mathrm{ml} 1 \mathrm{~N} \mathrm{HCl}$ for 1 hour in a microscrew-capped tube. After being cooled to room

Fig. 14. ${ }^{2} J_{\mathrm{C}-\mathrm{D}}$ coupling pattern and isotope shift of sodium $\left[1,2-{ }^{13} \mathrm{C}_{2}\right]$ acetate incorporated chrymutasin $\mathrm{A}$ (1).
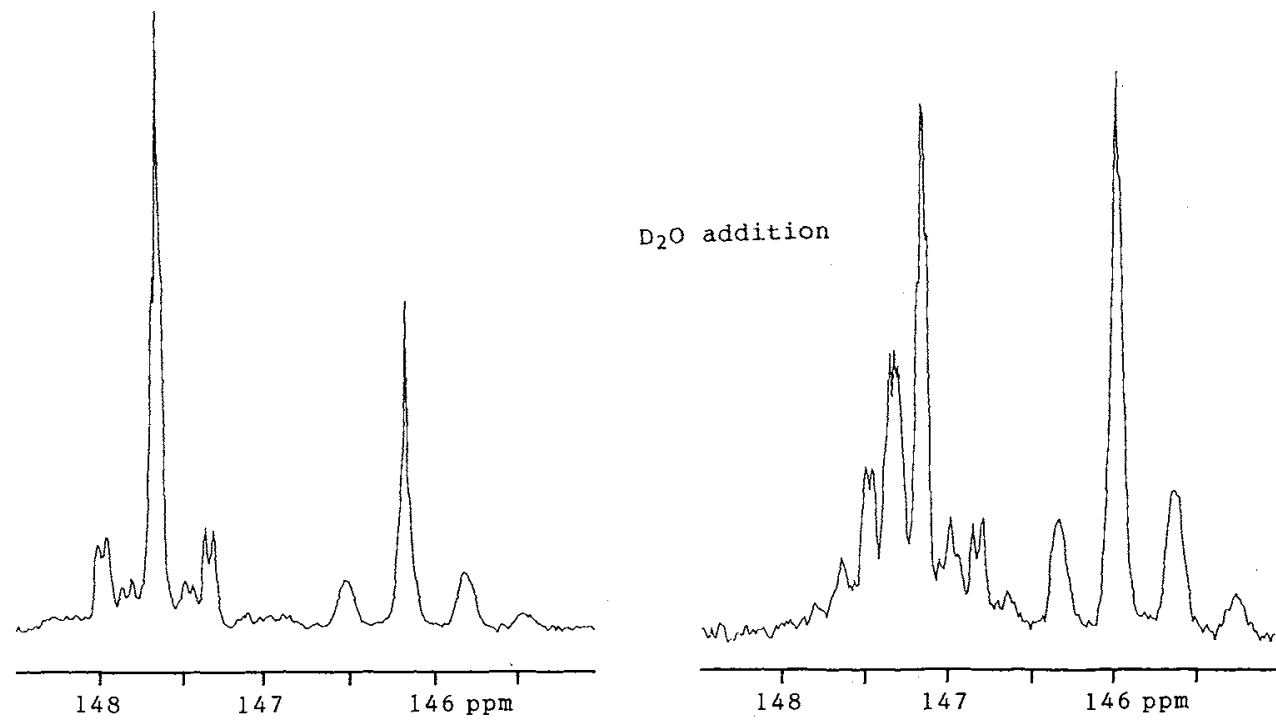

Scheme 1. Reductive acetylations of $\mathbf{1}$ and $\mathbf{8}$.

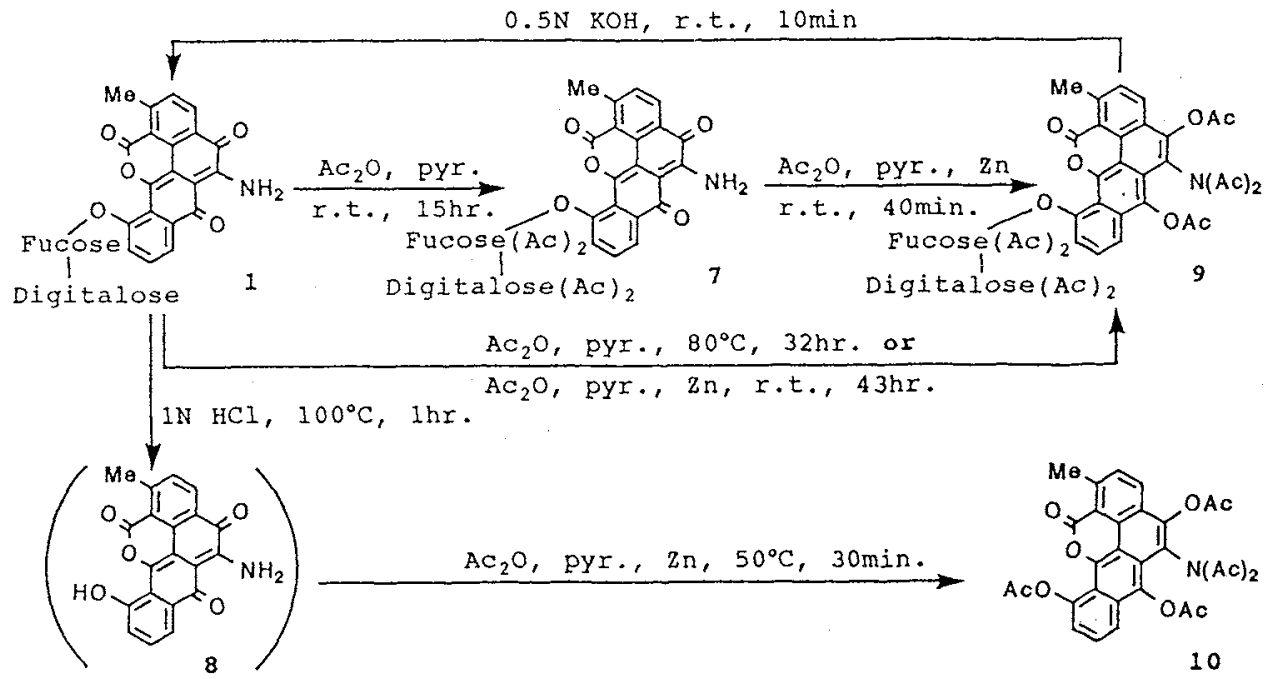


temperature, the solution was filtered through filter paper and completely evaporated to dryness, followed by trimethylsililation with a commercially available kit (TMS-HT solution, consisted of trimethylchlorosilane, hexamethyldisilazane and pyridine, Tokyo Kasei Kogyo Co., Ltd.). The resulting reaction mixture solution was filtered using a $0.45 \mu \mathrm{m}$ filter, and was analyzed using GC-EI-MS (column: SPB-5, Supelco, Inc., i.d. $0.53 \mathrm{~mm} \times 15 \mathrm{~m}$; carrier gas: $\mathrm{He}, 10.0 \mathrm{ml} /$ minute; oven temperature: $120^{\circ} \mathrm{C}$ for 6 minutes and heated $5^{\circ} \mathrm{C} /$ minute to $230^{\circ} \mathrm{C}$ ) for the MS fragment pattern and with GC (column: $3 \% \mathrm{SE}-30$ on Chromosorb W, i.d. $3 \mathrm{~mm} \times 1 \mathrm{~m}$; carrier gas: $\mathrm{N}_{2}, 30.0 \mathrm{ml} /$ minute; oven temperature: $130^{\circ} \mathrm{C}$ ) detected using FID for chromatogram integration.

In addition, a small part of the precipitate (8) on the filter paper was dissolved in DMSO and analyzed by HPLC. (column: Shiseido Co., Ltd., Capcell Pak $\mathrm{C}_{18}$, SG120 $\AA, 5 \mu \mathrm{m}$, i.d. $4.6 \times 150 \mathrm{~mm}$; eluent: $\mathrm{CH}_{3} \mathrm{CN}-\mathrm{H}_{2} \mathrm{O}$ (1:1); Flow rate; $1 \mathrm{ml} /$ minute; Retention time; 8.3 minute).

Compounds 2 and 3 were treated using the same procedure described above. The aglycones obtained from $\mathbf{2}$ and $\mathbf{3}$ showed the same retention time as that of $\mathbf{1}$.

\section{Labeled Compounds}

Sodium $\left[1-{ }^{13} \mathrm{C}\right]$ acetate $\left(99 \%{ }^{13} \mathrm{C}\right.$ enriched), sodium $\left[2-{ }^{13} \mathrm{C}\right]$ acetate $(99 \%)$ and sodium $[1,2-$ ${ }^{13} \mathrm{C}_{2}$ ]acetate $(99 \%)$ were purchased from Aldrich Chemical Co.

Fermentation with Singly and Doubly Labeled Sodium Acetate

S. chartreusis D329-185 (FERM BP-3269) strain was cultivated in $5 \times 3$ liter bottles containing each $600 \mathrm{ml}$ of fermentation medium (dry yeast $1.0 \%, \mathrm{~K}_{2} \mathrm{HPO}_{4} 0.2 \%, \mathrm{MgSO}_{4} \cdot 7 \mathrm{H}_{2} \mathrm{O} 0.1 \%$, mannitol $2.0 \%$, $\mathrm{FeSO}_{4} \cdot 2 \mathrm{H}_{2} \mathrm{O} 0.00001 \%, \mathrm{MnCl}_{2} \cdot 4 \mathrm{H}_{2} \mathrm{O} 0.00001 \%, \mathrm{ZnSO}_{4} \cdot 7 \mathrm{H}_{2} \mathrm{O} 0.00001 \%, \mathrm{CuSO}_{4} \cdot 5 \mathrm{H}_{2} \mathrm{O} 0.00001 \%$, $\mathrm{CoCl}_{2} \cdot 6 \mathrm{H}_{2} \mathrm{O} 0.00001 \%$, adjusted to $\mathrm{pH} 8.0$ ). Sodium $\left[1-{ }^{13} \mathrm{C}\right]$ acetate was dissolved in water at a concentration of $15 \mathrm{mg} / \mathrm{ml}$, and the solution was filtered with a $0.45 \mu \mathrm{m}$ filter in order to sterilize. Twenty $\mathrm{ml}$ aliquots of the solution per flask were added on 4, 7,11 and 14 days after inoculation. The fermentation was carried out on a rotary shaker at $30^{\circ} \mathrm{C}$ for 19 days.

In the case of sodium $\left[2-{ }^{13} \mathrm{C}\right]$ acetate, the strain was cultivated in $3 \times 3$ liter bottles each containing $600 \mathrm{ml}$ of the same medium, the solution of sodium $\left[2-{ }^{13} \mathrm{C}\right]$ acetate was added on $4,7,11$ days $(11 \mathrm{mg} / \mathrm{ml}$, $20 \mathrm{ml}$ perday), and the fermentation was carried out for 14 days.

In the case of sodium $\left[1,2-{ }^{13} \mathrm{C}_{2}\right]$ acetate, the strain was cultivated in $3 \times 3$ liter bottles each containing $600 \mathrm{ml}$ of the same medium, the solution of sodium $\left[1,2-{ }^{13} \mathrm{C}_{2}\right]$ acetate was added on $4,7,11$ days $(11.5 \mathrm{mg} / \mathrm{ml}$, $20 \mathrm{ml}$ perday), and the fermentation was carried out for 16 days.

\section{Preparation of Tetraacetate Derivative of 1}

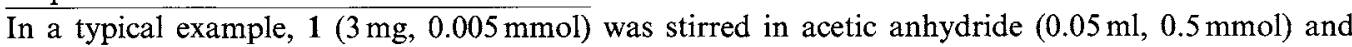
pyridine $(0.05 \mathrm{ml}, 0.6 \mathrm{mmol})$ at room temperature for 15 hours. The resulting reaction mixture was evaporated as a toluene azeotrope. Crude 7 was purified by HPLC (UV detection at $570 \mathrm{~nm}$ ) on a Capcell Pak $\mathrm{C}_{18}$ column (i.d. $6 \times 250 \mathrm{~mm}$ ), eluent: $\mathrm{H}_{2} \mathrm{O}-\mathrm{CH}_{3} \mathrm{CN}(1: 1)$, flow rate $1.5 \mathrm{ml} / \mathrm{minute}$, retention time 32.8 minutes, to give pure $7(2 \mathrm{mg}, 53 \%) .{ }^{1} \mathrm{H}$ NMR $\left(\mathrm{CDCl}_{3}, 55^{\circ} \mathrm{C}\right) \delta 2.22,2.10,2.07,1.10$ (each $3 \mathrm{H}, \mathrm{s}$, Ac); FD-MS $m / z 819\left(\mathrm{M}^{+}\right)$.

\section{Preparation of Reductive-acetate Derivative of 1}

In a typical example, acetic anhydride $(0.5 \mathrm{ml}, 5 \mathrm{mmol})$ and catalytic amount of zinc powder were added to $1(9.7 \mathrm{mg}, 0.015 \mathrm{mmol})$ in pyridine $(0.5 \mathrm{ml}, 6 \mathrm{mmol})$. After being stirred at room temperature for 43 hours, the reaction mixture was filtered through a $0.45 \mu \mathrm{m}$ filter to remove the zinc powder and evaporated as a toluene azeotrope. Crude 9 was purified by preparative TLC (Merck, Art. 13895, nhexane-acetone $6: 4,4$ developments), to give pure $9(7.4 \mathrm{mg}, 50 \%)$ as a somewhat unstable (could be oxidized in air) yellow compound. 9: $\mathrm{C}_{49} \mathrm{H}_{51} \mathrm{NO}_{21}$; FAB-MS (positive): $m / z 1028(\mathrm{M}+\mathrm{K})^{+}, 1012$ $(\mathrm{M}+\mathrm{Na})^{+}, 990(\mathrm{M}+\mathrm{H})^{+}$; (negative): $m / z 989\left(\mathrm{M}^{-}\right) ;{ }^{1} \mathrm{H}$ NMR $\left(\mathrm{C}_{6} \mathrm{D}_{6}, 400 \mathrm{MHz}, 50^{\circ} \mathrm{C}\right) \delta 2.85,2.33$, $2.22,2.08,1.89,1.72,1.53,1.34$ (each $3 \mathrm{H}, \mathrm{s}, \mathrm{Ac}$ ); UV $\lambda_{\max } \mathrm{nm}$ at neutral pH: $258,273,292,304,383,404$, 427 (this UV spectrum was measured with a HPLC system having a photodiode array in order to eliminate the decomposed products from the pure sample, therefore, ss could not been calculated).

Compound 9 was also obtained from 1 or 7 in the following conditions: 1 was stirred in acetic 
anhydride and pyridine at $80^{\circ} \mathrm{C}$ for 32 hours and purification.; 7 was stirred in acetic anhydride, pyridine, and a catalytic amount of zinc powder at room temperature for 40 minutes and purification.

\section{Hydrolysis of 9}

$1 \mathrm{~N} \mathrm{KOH} 100 \mu \mathrm{l}$ and a small amount of 9 in $\mathrm{MeOH} 100 \mu \mathrm{l}$ were stirred at room temperature for 10 minutes. The reaction mixture was analyzed with TLC. The yellow spot (9) disappeared and a purple spot that had the same Rf value of 1 (Table 2) was newly detected. The new purple compound also showed the same retention time in comparison with 1 by HPLC analysis. (column: Shiseido Co., Ltd., Capcell Pak $\mathrm{C}_{18}, \mathrm{SG} 120 \AA$, $5 \mu$ m, i.d. $4.6 \times 150 \mathrm{~mm}$; eluent: $\mathrm{CH}_{3} \mathrm{CN}-\mathrm{H}_{2} \mathrm{O}(3: 7)$; flow rate: $1 \mathrm{ml} /$ minute; retention time: 6.0 minutes).

\section{Preparation of Reductive-acetate Derivative of $\mathbf{8}$ (the Aglycone of $\mathbf{1}$ )}

Crude $1(9.1 \mathrm{mg}, 0.014 \mathrm{mmol})$ was hydrolyzed in $1 \mathrm{~N} \mathrm{HCl} 2 \mathrm{ml}$ at $100^{\circ} \mathrm{C}$ for 1.5 hours. The resulting precipitate was filtered, followed by being reductively-acetylated. Crude 8 was stirred in acetic anhydride and pyridine in addition of a catalytic amount of zinc powder at $50^{\circ} \mathrm{C}$ for 30 minutes. The crude 10 obtained was purified by preparative TLC (Merck, Art. 13895, $\mathrm{CH}_{2} \mathrm{Cl}_{2}-\mathrm{MeOH} 99: 1$ ), to give pure 10 $(2.7 \mathrm{mg}, 35 \%)$ as a somewhat unstable yellow compound. 10: $\mathrm{C}_{30} \mathrm{H}_{23} \mathrm{NO}_{10}$; HREI-MS: $\mathrm{m} / z$ Found $557.1333\left(\mathrm{M}^{+}\right)$, Calcd. 557.1322; ${ }^{1} \mathrm{H}$ NMR $\left(\mathrm{CDCl}_{3}, 400 \mathrm{MHz}\right.$, room temperature $) \delta 8.00(1 \mathrm{H}, \mathrm{d}, J=$ $8.2 \mathrm{~Hz}), 7.80(1 \mathrm{H}, \mathrm{d}, J=8.2 \mathrm{~Hz}), 7.78(1 \mathrm{H}, \mathrm{dd}, J=8.7,1.2 \mathrm{~Hz}), 7.72(1 \mathrm{H}, \mathrm{dd}, J=8.7,7.2 \mathrm{~Hz}), 7.41(1 \mathrm{H}$, $\mathrm{dd}, J=7.2,1.2 \mathrm{~Hz}), 3.12(3 \mathrm{H}, \mathrm{s}), 2.74(3 \mathrm{H}, \mathrm{s}), 2.53(3 \mathrm{H}, \mathrm{s}), 2.48(3 \mathrm{H}, \mathrm{s}), 2.40(6 \mathrm{H}, \mathrm{s})$.

\section{Acknowledgement}

The authors express their deep thanks to Dr. T. Kusumr (University of Tsukuba, Present address: University of Tokushima) for experimental advice and NMR measurements.

\section{References}

1) Uchida, H.; Y. Nakakita, N. Enoki, N. Abe, T. Nakamura \& M. Munekata: Chrymutasins: a new type of aglycone related to chartreusin; novel antitumour antibiotics from a mutant of Streptomyces chartreusis. J. Chem. Soc. Chem. Commun. 1994: 323 324, 1994

2) Leach, B. E.; K. M. Calhoun, L. E. Johnson, C. M. Teeters \& W. G. Jackson: Chartreusin, a new antibiotic produced by Streptomyces chartreusis, a new species. J. Am. Chem. Soc. 75: 4011 4012, 1953

3) Aoyama, Y.; T. Katayama, M. Yamamoto, H. Tanaka \& K. Kon: A new antitumor antibiotic product, demethylchartreusin isolation and biological activities. J. Antibiotics 45: 875 878, 1992

4) Uchida, H.; Y. Nakakita, N. Enoki, N. Abe, T. Nakamura \& M. Munekata: A novel compound related to chartreusin from a mutant of Streptomyces chartreusis. J. Antibiotics 46: $1611 \sim 1615,1993$

5) Uchida, H.; Y. Nakakita, N. Enoki, N. Abe, T. Nakamura \& M. Munekata: Chrymutasins: Novel-aglycone antitumor antibiotics from a mutant of Streptomyces chartreusis. I. Taxonomy, mutation, fermentation, isolation and biological activities. J. Antibiotics 47: 648 654, 1994

6) Simonitsh, E.; W. Eisenhuth, O. A. Stamm \& H. Schmid: Über die Struktur des Chartreusins I. Helv. Chim. Acta 47: $1459 \sim 1484,1964$

7) Canham, P. L.; L. C. Vining, A. G. Mcinnes, J. A. Walter \& J. L. C. Wright: Use of ${ }^{13}$ C in biosynthetic studies. Incorporation of ${ }^{13} \mathrm{C}$-labeled acetate into chartreusin by Streptomyces chartreusis. Can. J. Chem. 55: 2450 2457, 1977 